\title{
Mind the gap: Modelling the liability of online auction intermediaries and market places in Hong Kong on the EU regime
}

\author{
Dr Christine Riefa, Brunel University London ${ }^{1}$ \\ Dr Jojo YC Mo, City University of Hong Kong ${ }^{2}$
}

In Hong Kong, online auctions and market places ${ }^{3}$ providers are well established. Yahoo! Auction, launched in 1999, boasts 1.5 million monthly unique visitors and 5.5 transactions every minute of an average value of HKD $424 .{ }^{4}$ Similarly, Taobao ${ }^{5}$, the market leader in China ${ }^{6}$, counts 1.4 million users in Hong Kong and is one of the most visited sites in the world by volume of traffic. ${ }^{7}$ On these platforms, as is the case in many jurisdictions, the sale of fake items and other forms of intellectual property infringements are an all too common occurrence

\footnotetext{
${ }^{1}$ Dr Christine Riefa, Reader, Christine.riefa@brunel.ac.uk. This paper is based on a talk given to staff at the Law School, City University Hong Kong during a research visit in March 2015.

2 Dr Jojo YC Mo, Assistant Professor, School of Law, City University of Hong Kong, yunchimo@um.cityu.edu.hk.

${ }^{3}$ A distinction needs to be drawn between market places that enables third parties to exchange, or by and sell goods and services using fixed price models and online auction sites on which auctions are organized as a method of sale. However note that the distinction is eroding and many online auction sites in the world are now not always predominantly using auctions as a mode of sale but have also enabled users to transact using fixed price methods. For more on this issue, see Christine Riefa, Consumer Protection and Online Auction Platforms: towards a safer legal framework (Routledge 2015) 8.

${ }^{4}$ Yahoo! $<$ https://hk.auctions.yahoo.com>. The site also now has its own payment system Yahoo PAY, equivalent to Paypal for eBay < http://www.campaignasia.com/Article/365887,Ya$\underline{\text { hoo }+ \text { PAY }+ \text { goes }+ \text { live }+ \text { in }+ \text { Hong }+ \text { Kong.aspx }}>$ accessed 24 May 2016. Note that eBay is also active in Hong Kong but has a much lower market share.
}

5 Taobao $<$ http://hk.taobao.com $>$ accessed 24 May 2016.

${ }^{6}$ According to figures by Alexa, the site ranks second, by volume of traffic, after Baidu, the Chinese search engines (http://www.alexa.com/topsites/countries/CN accessed 24 May 2016). The site is also ranked $9^{\text {th }}$ in the world by volume of traffic, mostly originating in China. See, $<\underline{\text { http://www.alexa.com/siteinfo/taobao.com }>\text { ac- }}$ cessed 24 May 2016.

${ }^{7}<$ http://www.alexa.com/siteinfo/taobao.com $>$ accessed 24 May 2016. 
despite measures in place to curb them. ${ }^{8}$ In Hong Kong, enforcement actions conducted in 2014 alone on auction sites and social networks, led to the seizure of ' 11,796 items of suspected counterfeit goods with a total value of about HK\$1.12 million. A total of 45 persons, including 21 men and 24 women aged from 14 to 58, were arrested. ${ }^{9}$ But for consumers and IP owners, considering intermediary online auction sites and market place providers liable for the activity of third parties and the goods sold on their sites is a more convenient way to obtain redress, mostly because the financial strength of the intermediary is likely to be far greater than any of the sellers using the site and its identity and location are readily available, making proceedings against the site much simpler. It is also a useful tool because, often, the auction platform is better placed to detect and stop the infringements and other frauds committed via its intermediary than individual buyers or national enforcers may be.

However, in many jurisdictions, legislation was adopted to carve out 'safe harbour' provisions protecting intermediaries. ${ }^{10}$ This is for example the case in the USA under Section 230 of the Communications Decency Act. Similar exemptions also exist in China for copyright infringement in particular, although to a different degree. In the EU Directive 2000/31/EC of 8 June

\footnotetext{
${ }^{8}$ See for example, the 'E-auctioning with Integrity' scheme, a collaboration between eBay, Yahoo! Auctions and Customs and Excise in Hong Kong, designed to curb infringements < $\underline{\text { https://www.iprpa.org/eng/auc- }}$ tionscheme.php $>$ accessed 24 May 2016

. Note that a trend towards an increase in infringement on social media platforms has been detected (see http://www.asiaiplaw.com/article/7/1829/ accessed 24 May 2016). Also note reports of low levels of copyright infringements by the International Intellectual Property Alliance (IIPA 2014 Special 301 report on copyright protection and enforcement, <http://www.iipa.com/rbc/2014/2014SPEC301HONGKONG.PDF> accessed 24 May 2016, 191).

${ }^{9} \mathrm{http}: / /$ www.asiaiplaw.com/article/7/1829/ accessed 24 May 2015.

${ }^{10}$ See Daniel Seng, Comparative analysis of the national approaches to the liability of Internet intermediaries (preliminary version) $<$ http://www.wipo.int/export/sites/www/copyright/en/doc/liability_of_internet_intermediaries.pdf $>$ accessed 24 May 2015, 21.
} 
2000 on Electronic Commerce (ECD) ${ }^{11}$ also offers protection from liability for hosting activities $^{12}$ under Article 14 ECD. ${ }^{13}$ The rationale for the adoption of a shield against liability is chiefly anchored in encouraging the development of intermediary activities which would be hampered if Internet Service Providers (ISPs) were overly burdened with liability for the third party content they carried. In Hong Kong no such general shield exists.

\section{Rationale for bridging the liability gap in Hong Kong}

There is a gap in the way online auctions and market places' liability is defined in Hong Kong. There is indeed, no specific legislation to define the parameters within which Internet intermediaries hosting content for third parties can operate and what liability they ought to shoulder. The regime applicable has been suggested to be one of strict liability ${ }^{14}$ but it is not certain how such regime would be applied in practice. Internet intermediaries, whether they are ISPs or auction market platforms, may need to rely on different pieces of legislation. Protection is thus on a piecemeal basis. Worse, these intermediaries may often find themselves attracting civil liabilities (e.g. in the areas of defamation and copyright) even though they may not have any knowledge about the activity in question. The current framework in place in Hong Kong to

\footnotetext{
${ }^{11}$ Directive 2000/31/EC of 8 June 2000 on certain legal aspects of information society services, in particular electronic commerce, in the internal market [2000] OJ L178/1. In the UK, this Directive was implemented via the Electronic Commerce (EC Directive) Regulations 2002, SI 2002/2013.

12 Hosting consists in the storage of content for third parties.

${ }^{13}$ This article offers a defence against damages claims and criminal liability in cases where 'a) the provider does not have actual knowledge of illegal activity or information and, as regards claims for damages, is not aware of facts or circumstances from which the illegal activity is apparent; or b) the provider, upon obtaining such knowledge or awareness, acts expeditiously to remove or disable access to the information.' Article 14 was implemented in the UK via Regulation 19 Electronic Commerce (EC Directive) Regulations 2002, SI 2002/2013.

${ }^{14}$ Freidmann Danny, 'Sinking the safe harbor with the legal certainty of strict liability in sight' (2014) 9(2) Journal of Intellectual Property Law \& Practice 155.
} 
control liability for defamation and copyright infringement is, in our view, unhelpful regarding the liability of online auction intermediaries as explained below.

\subsection{Unsatisfactory Defamation laws}

Online auction platforms or other online intermediaries may offer bulletin boards or forums to facilitate communications between the users of their services. Such bulletin boards enable users to participate in exchanges with others, and they can view other members' messages or post their own messages as they wish. Intermediaries may be liable for messages if they are considered to be publishers in common law. Further issues can arise if hyperlinks are used since materials contained in a hyperlinked publication may constitute publication. The internet is an extremely flexible medium of communication and enables easy publication of different forms of material including pictures, videos and sounds. The question therefore is what amounts to publication and whether such intermediaries are regarded as publishers. The traditional common law rule is that a person who intentionally or negligently takes part in the publication of another's defamatory material is equally responsible for the publication as the original author. ${ }^{15}$ This is especially true when the intermediary failed to remove another's defamatory posting within its control. ${ }^{16}$

\footnotetext{
${ }^{15}$ Matthew Collins, The Law of Defamation and the Internet (3 ${ }^{\text {rd }}$ edn Oxford University Press 2010) 101.

${ }^{16}$ See Byrne v Deane [1937] 1 KB 818.
} 
It is indeed a regime anchored in the common law that has mostly focused on controlling liability for defamatory materials. ${ }^{17}$ The case of Oriental press Group Limited v Fevaworks Solutions $L t d^{18}$ in 2012 was the first Hong Kong decision taken by the Court of Final Appeal on website host liability. ${ }^{19}$ Whilst the respondents are forum operators and not online auction platforms, an analogy can be made particularly when web users are allowed to ask questions or post comments on these online auction platforms. In Fevaworks, the plaintiffs brought actions of libel against the defendants. The defendants were operators of a website which host a popular discussion forum for a variety of interests. Messages alleging the plaintiffs involving in triad and criminal activities were posted on the forum. At first instance, the court found that the defendants were not primary publishers but subordinate publishers. They were not liable because the defence of innocent dissemination was successfully invoked. The plaintiffs appealed to the Court of Final Appeal. At issue was whether internet discussion forums could be regarded as publishers and if so, the extent to which such publishers could rely on the common law defence of innocent dissemination.

The court found for the defendants and held that whether or not a person is the main publisher depends on two things. A person is a primary publisher if he knew or could have easily acquired knowledge of the content of article in question ('the knowledge criterion') and that he had the ability to control or to prevent the publication of such content ('the control criterion'). Ribeiro $\mathrm{J}$ held that the defendants were publishers from the outset because they facilitated and participated in the process throughout. His Honour further concluded that the principles in Byrne $v$

\footnotetext{
${ }^{17}$ Paul Stephenson and Alisa Kwan, Cyberlaw in Hong Kong ( ${ }^{\text {rd }}$ edn Lexis Nexis 2014) 88-91; Rebecca Ong, Liability of Internet Intermediaries for user-generated content: an examination of Oriental Press Group Ltdv Fevaworks Solutions Ltd (2015) 31 Computer Law \& Security Review 131-38.

${ }^{18}$ [2013] 16 HKCFAR 366.

${ }^{19}$ Ong (n 17) 131.
} 
Deane $^{20}$ do not apply to internet platform providers because such providers are in a totally different position from that of a proprietor of a club (as seen in Byrne) who is not in the business of publishing at all. The court further held that the defendants in fact played an active role in encouraging postings in the forum. ${ }^{21}$ Relying on Thompson v Australian Capital Television Pty $L t d^{22}$, the court accepted that 'any disseminator of a libel publishes the libel but, if he can establish the defence of innocent dissemination, he will not be responsible for that publication. ${ }^{, 23}$ Whilst the court considered the defendants to be publishers at the outset, it differed from the conclusion in Thompson. In Thompson, the defendant was liable as the main publisher for re-broadcasting a live programme produced by Channel 9 because it was the defendant's choice that the telecast is as near instantaneous and the defendant had full control of how and when the programme is to be transmitted. Ribeiro $\mathrm{J}$ in Fevaworks observed that publications over the internet are very different from a broadcasting channel in the sense that the internet involves an interactive, 'many-to-many' communications which is different from the 'one-tomany' model that broadcasting channels adopt.

The Fevaworks case established the control test and the knowledge test in determining liability for forum operators but the decision is not clear cut. As seen from the above, the court agreed that any disseminator publishes a libel unless he or she can raise the defence of innocent dissemination. The effect is to place the burden on the defendant to raise the defence, even if he or she had little or no control over the publication. Although an online intermediary exercising minimal control over the publication of material by web users is likely to invoke the defence

\footnotetext{
${ }^{20}$ [1937] 1 K.B. 818.

${ }^{21}$ In fact the defendants designed its forum to be a user-friendly one permitting users to browse and post on their forum as well as employing administrators to monitor the users' discussions.

22 (1996)186 CLR 574, 586.

${ }^{23}$ Fevaworks (n 18) 381.
} 
of innocent dissemination successfully, it arguable whether such mere facilitators should be regarded as publishers from the outset and if they are not regarded as publishers, they should not be given the burden to raise the defence.

In any event, it may not be ideal to rely on developments in case law in an area that is evolving at such a fast pace. It is unfortunate that the Hong Kong Defamation Ordinance (DO ${ }^{24}$ does not contain a provision similar to section 1 of the United Kingdom's Defamation Act 1996 which categorises the roles of authors, editors and publishers. The statutory defence in section $25 \mathrm{DO}$ is of limited assistance since it is only available to those who unintentionally published defamatory materials and the defence can only be used provided that an offer of amends is made by the defendant. Unless there is a specific provision ${ }^{25}$ which offers specific protection to online intermediaries, such intermediaries may only rely on the Fevaworks decision which may not be satisfactory.

\subsection{Unsatisfactory Copyright Laws}

Another area where online auction platforms may be liable for another person's act is in the area of copyright. Section 22 of the Hong Kong Copyright Ordinance ${ }^{26}$ states that copyright in a work is infringed if a person, without the licence of the copyright owner, does or authorises another to do any of the acts restricted by copyright. Section 22(1) further lists out such restricted acts and includes copying and making available copies of the work to the public. In the context of online auction platforms and marketplaces, such entities may find themselves liable if users of these platforms make available for sale counterfeit products, since they may have

\footnotetext{
${ }^{24}$ Cap. 21.

${ }^{25}$ See s 5 and 10 of the UK Defamation Act 2013 which offer specific protection to online intermediaries.

${ }^{26}$ Cap. 528.
} 
'authorised' such transactions. There is no direct Hong Kong authority in this area but applying the UK case of CBS Songs Ltd v Amstrad Consumer Electronics Plc, ${ }^{27}$ to authorise means to 'grant or purport to grant to a third person the right to do the act complained of, whether the intention is that the grantee shall do the act on his own account or only on account of the grantor. ${ }^{28}$ The defendant was not liable in this case because the court found that the defendant had no control over how the purchasers would use their twin-deck recorders. The defendant may have facilitated the process but did not authorise as such. By analogy, an online auction platform may be liable for copyright infringing acts by their users if it had knowledge and control over such acts. Thus, it is likely that the online auction platform is liable for the sale of counterfeit goods by their members if they had knowledge about it but did not take actions to prevent it.

The uncertainty in this area is fortunately considered by the Copyright (Amendment) Bill 2014. ${ }^{29}$ This Bill proposes the establishment of a statutory 'safe harbour' for online service providers ('OSPs') provided such OSPs meet certain prescribed conditions, including taking reasonable steps to limit or stop copyright infringing activities upon notification. To avail to such a defence, the OSP must not have any financial benefit directly attributable to the infringement ${ }^{30}$ There is no general requirement to monitor ${ }^{31}$ and when an OSP becomes aware of a copyright infringing activity, the OSP may remove the material in question and notify the subscriber of such removal. ${ }^{32}$ The affected subscriber may, within a reasonable time after receiving

\footnotetext{
${ }^{27}$ [1988] AC 1013.

${ }^{28}$ Ibid 1054.

$29<$ http://www.gld.gov.hk/egazette/pdf/20141824/es32014182421.pdf $>$ accessed 24 May 2016.

${ }^{30}$ Section 88B Copyright (Amendment) Bill 2014.

${ }^{31}$ Ibid s $88 \mathrm{~B}(5)$.

${ }^{32}$ Ibid s $88 \mathrm{D}$.
} 
notice of alleged copyright infringement, give a counter-notice to the $\mathrm{OSP}^{33}$ disputing or denying the infringement. OSPs are further protected from liability for removal of material provided that the OSP has, in good faith, removed such material pursuant to a notice of alleged infringement and this applies whether or not the alleged activity is ultimately determined to be infringing or not. ${ }^{34}$

However the progress on the legislation and its associated code of practice so far has been put on a halt ${ }^{35}$ and may only offer limited solutions to the control of infringing materials on online auction platforms that fall within the remit of this Bill. Whilst these new provisions provide a 'safe harbour' for OSPs, it is likely that OSPs will remove any material upon notice since the legislation does not specify a timeframe in which an OSP is required to act. It is unlikely that OSPs will take the risk and investigate the legality of the activity complained of, particularly when they are further protected by section $88 \mathrm{H}$ where OSPs' liabilities for removal of materials are exempted provided that they acted in good faith. In any event, OSPs are generally not required to monitor contents on their platform. Does it mean that OSPs are discouraged to administer the contents of their platform since more active editorial control may work against them? The Bill is silent on the standard of care required by OSPs. In any event, it may also be doubtful as to whether these new provisions would apply to online auction sites since these sites receive a commission ${ }^{36}$ even on counterfeit products and thus receive benefits directly

\footnotetext{
${ }^{33}$ Ibid s $88 \mathrm{E}$.

${ }^{34}$ Ibid s $88 \mathrm{H}$.

$35<$ http://www.ipd.gov.hk/eng/intellectual_property/copyright/Keynote_2014_e.pdf> accessed 24 May 2016.
} The government also consulted on the creation of a Code of Practice setting out guidelines, that would underpin the legislation, but to date this initiative has stalled.

${ }^{36}$ Christine Riefa, 'To be or not to be an auctioneer? Some thoughts on the legal nature of online "eBay" auctions and the protection of consumers' (2008) 31 Journal of Consumer Policy 167. 
attributable to the infringement, a condition which is specifically stated in section $88 \mathrm{~B} 2$ (b) of the Copyright (Amendment) Bill 2014.

\subsection{The need for reform}

The debate on intermediary liability is gathering pace in Hong Kong. Some authors are calling for strict liability for ISPs ${ }^{37}$, while others feel a greater level of protection for intermediaries is necessary at least in defamation $\operatorname{cases}^{38}$, but none have to date precisely focused on the position of online auction intermediaries such as Yahoo!, Taobao or eBay. This is especially true when such intermediaries are facing different forms of liability and yet the laws governing each form of liability can be uncertain and confusing. Those online auction sites may, in any event, be liable for more than defamatory materials or copyright infringement. Liability on those sites may encompass trademark infringements (sale of fake goods for example) as well as liability for goods that are not delivered or faulty for example. It is therefore timely to reflect on how liability would apply to online auction platforms and other market places and how Hong Kong may go about bridging its liability gap.

This article reflects on the possibility of using the EU regime, to serve as a starting point to defining the liability of online auction sites in Hong Kong, having considered the suitability of other regimes.

\footnotetext{
${ }^{37}$ See for example, Freidmann Danny (n14) 148-155.

${ }^{38}$ Cheung Anne. S.Y, Liability of Internet host providers in Defamation actions: from gatekeepers to identifiers (2014) Faculty of Law Research papers No. 2014/013, 5 <http://ssrn.com/abstract=2428566> accessed 24 May 2016; Ong (n 17) 131.
} 


\section{Which liability model for Hong Kong online auction intermediaries?}

Essentially, the legislator and courts may choose between three models that broadly speaking offer immunity from third party infringements, but all do so to different degrees. ${ }^{39}$ At one end of the spectrum, the US regime has been very protective of hosts denying all claims for liability on a number of grounds. ${ }^{40}$ The liability of eBay was extensively tested in the USA but the online auction site has always been triumphant. It found shelter under the Digital Millennium Copyright Act in Hendrickson v. eBay ${ }^{41}$ where the court considered that it was not liable for secondary copyright infringement having facilitated the distribution of infringing DVDs, because it did not have knowledge of the infringing copyright activities, this despite a notice having been served. According to the court, the notice was not compliant with the legislative requirement and thus eBay could in effect ignore it. Another effective shield for eBay was section 230 of title 47 of the United States Code which creates a federal exemption to any state law that would hold ISPs liable for information originating with a third party. In Randall Stoner v. eBay $I n c^{42}$ the court placed the threshold for immunity rather low explaining that for eBay to lose it, actual knowledge as well as affirmative action going beyond simply making its facilities available was necessary. ${ }^{43}$ Similarly in Tiffany (NJ) Inc. and Tiffany and Company $v$ eBay $\operatorname{Inc}{ }^{44}$, the court ruled that eBay's use of jewellery company Tiffany's trademarks was protected under nominative fair use. It rejected claims that eBay should be liable because the

\footnotetext{
${ }^{39}$ For more details, See Seng (n 10) 21.

${ }^{40}$ Dawn Osborne, 'User generated content (UGC): trade mark and copyright infringement issues' (2008) 3(9) Journal of Intellectual Property and Practice 555-62, 555.

412001 WL 1078981, (C.D. Cal. 2001, Sept 4, 2001).

422000 WL 1705637, Civ. No. 305666, (Sup. Ct. Ca., November 7, 2000).

${ }^{43}$ See also Lars Gentry v. eBay Inc [121 Cal. Rptr. 2d 703, (Cal App. 2002)].

${ }^{44}$ United States District Court Southern District of New York, Case N04 Civ 4607 (RJS), 14 July 2008.
} 
site knew or had reason to know of the infringement at issue and should have done more to stop it from occurring. ${ }^{45}$ The American regime is thus very protective of intermediaries.

By contrast, Chinese law places the most stringent expectations on intermediaries. There are various pieces of legislation in China which regulate ISPs liability in China and the major ones are Tort Law ${ }^{46}$, Provisions of the Supreme People's Court on Several Issues concerning the Application of Law in Hearing Civil Dispute Cases Involving Infringement of the Right of Dissemination on Information Networks ${ }^{47}$ and the Regulation on the Protection of the Right to Communicate Works to the Public over Information Networks ('the 2013 Regulations'). Article 36 of the Tort Liability Law states that if an ISP knows that its user has used the ISP's network to infringe the civil rights of another person and does not take appropriate action, the ISP shall be jointly liable together with the user. The party who suffered from the infringing activity is entitled to request the ISP to take necessary measures to protect his or her rights. If the ISP fails to take such measures in a timely manner, the ISP shall be jointly liable with the infringing user for increased damages caused by the tort. The Supreme People's Court further issued a document the 'Supreme People's Court Regulations concerning Some Questions of Applicable Law in Handling Civil Dispute Cases involving the Use of Information Networks to Harm Personal Rights and Interests' (SPC Regulations) ${ }^{48}$ to provide instructions to the People's Courts on civil cases involving harm to personality rights including persons' right to a name, right to reputation, portrait right, right to privacy and other such personal rights and

\footnotetext{
${ }^{45}$ See Christine Riefa, 'Tiffany (NJ) Inc. and Tiffany and Company v eBay Inc', (2008) 8 E-Commerce Law Reports16.

${ }^{46}$ Article 36 of the Tort Liability Law of the People's Republic of China.

${ }^{47}$ Interpretation No. 20 [2012] of the Supreme People's Court.

${ }^{48}$ See https://chinacopyrightandmedia.wordpress.com/2014/10/09/supreme-peoples-court-regulations-concerning-some-questions-of-applicable-law-in-handing-civil-dispute-cases-involving-the-use-of-information-networks-to-harm-personal-rights-and-interests/ accessed 24 May 2016.
} 
interests through the use of information networks. ${ }^{49}$ Article 4 of the SPC regulations made it mandatory for an ISP to disclose the identity and contact details of the suspected infringer to the court and failure to do that would result in punitive measures directed against the ISP. Article 5 also states the notice given by the aggrieved party should contain the name and contact method of the notifier, the indication and location of the harmful content as well as an explanation for deletion of such harmful content otherwise the ISP may be exempted from liability. Since the basis of liability under article 36 of the Tort Liability Law rests on knowledge, the SPC Regulations provide a list of factors in assessing knowledge including whether the ISP selected, recommended, edited or in other ways processed the harmful information; the ability to manage information; the type of rights infringed and the degree of clarity as to whether the information is unlawful; its social influence and hit rate; the technological possibility for the ISP to adopt preventive measures and whether reasonable measures were adopted in relation to repeating infringers. Thus it can be seen that ISPs will be jointly liable for the misconduct of subscribers in relation to the infringement of civil rights and shall include copyright infringement and defamation.

The 2013 regulations were adopted to address the concerns of online piracy and article 20 provides for a mere conduit defence for an ISP if it does not select or modify the work in question. Article 22 states that a network service provider that provides information storage space shall not be liable provided that it does not alter the work, does not know or has no justified reason to believe that the materials are infringing, has no directly obtained economic benefits from the infringing materials and deleted such materials after receiving notification from the copyright owner. Thus in Shanghai Xinchuan Online Co Ltd v Tudou.com Co Ltd ${ }^{50}$,

\footnotetext{
${ }^{49}$ Ibid article 1.

${ }^{50}$ Shanghai Super People's Ct. Jul 30, 2008.
} 
the operator of the video sharing website www.tudou.com was denied immunity simply because by organising the movies uploaded by its users into various channels, the court ruled that it knew of the possibility that infringing movies would be uploaded on its website. There was therefore an expectation that the site would monitor uploads and would remove any infringing ones expeditiously. Needless to say, this test is much more demanding that that devised in the EU (as explored further on) and there is no doubt that online auction sites, who do benefit financially from the placing of listing selling fake items would ensure that the host is denied immunity also.

The Chinese regime is specific and focuses on knowledge in considering ISPs liability. These considerations are roughly similar to those in the Copyright Amendment Bill 2014, which serves as a useful starting point in determining ISP's liability. However, this regime may not be appropriate for Hong Kong for several reasons. First, there are various pieces of legislation and regulations which govern the roles of ISPs and it is submitted that the EU regime which consists of a uniform code offers more clarity and certainty. Second, the legal basis in which ISPs are held liable in China rests with the joint-liability theory where the Chinese courts look to factors similar to those in the United States, e.g. knowledge, control, financial benefits arising from the transaction. ${ }^{51}$ - However, as seen from the above, the basis of liability under Hong Kong copyright laws lies with the concept of authorisation derived from English common law cases. The Chinese regime placed much emphasis on knowledge itself and an ISP will be jointly liable if it has knowledge that its user is engaged in infringing acts. The concept of authorisation is different from mere knowledge. As seen in the Amstrad case, the defendant was not liable because it had no control how the buyers would use the twin-deck recorders and

\footnotetext{
${ }^{51}$ See Seagull Haiyan Song, 'A Comparative Copyright Analysis of ISP Liability in China versus the United States Lawyer’ 27(7) 2010 The Computer \& Internet Lawyer 1, 8.
} 
this was not a case where the buyer will be 'bound to infringe'. As such, it is arguable that an ISP who has knowledge but lacks control over its subscribers is potentially liable under the Chinese regime. In most cases, Chinese courts will hold ISPs liable by interpreting an ISP's duty of care broadly. ${ }^{52}$ In a case involving deep linking in China, the defendant implemented framing and deep linking facilities to enable its users to search for movie resources on thirdparty websites. The court held that the defendant owed a higher duty of care than general search engines in view of the specific role that the defendant played. ${ }^{53}$ In relation to copyright cases, it is unlikely that the Hong Kong courts will impose a higher duty of care to a similar defendant but may find liability based on authorisation in view of the active role that it has played in the process. Thus, the basis in which liability is found is different. Third, provisions like article 4 of the SPC Regulations which mandatorily requires an ISP to disclose the contact details of the alleged infringer may not sit comfortably with Hong Kong's fundamental rights guaranteed under the Basic Law of Hong Kong. An ISP should be given the freedom not to act particularly when there are valid reasons to believe that the activities complained of are not unlawful. In any event, China is not a case-law jurisdiction and conflicting decisions and opinions are not uncommon. In IFPI v Baidu, ${ }^{54}$ Baidu provided a searching and linking facility and the court agreed that the safe harbour provisions should apply and further held that the IFPI's notice was defective and thus Baidu was not put on notice of the infringing activity. In IFPI $v$ Alibaba ${ }^{55}$, the facts were similar to the Baidu case but the court held that Alibaba should know or should have known that the search results contained infringing materials. Alibaba only deleted specific URL links as stated in the notice but failed to delete other links leading to the same materials.

\footnotetext{
52 See Ke Steven Wan, 'Internet Service Providers' Vicarious Liability Versus Regulation of Copyright Infringement in China' 2011 Journal of Law, Technology \& Policy 375, 382.

${ }^{53}$ Ibid. See Youdu v Xunlei (2007).

54 The Beijing First Intermediate Court, 2005 No. 7965 (2005). The Beijing High Court later affirmed the Intermediate Court's decision.

55 The Beijing High Court, 2007 No. 1190.
} 
The same court held that Alibaba was grossly negligent and was thus jointly liable for copyright infringement. Thus, the inconsistencies of these decisions may not be particularly useful in a precedent-based jurisdiction like Hong Kong.

\section{Using the $\mathbf{E U}$ regime as a starting point for Hong Kong}

The advantage of the EU regime developed under the Electronic Commerce Directive, and Article 14 in particular, is that it offers a uniform test to decide if an intermediary should be liable, which is not linked to the infringing or offending material but to the role the intermediary plays. It is also the regime that is applied in the UK, a jurisdiction the Hong Kong Judiciary is familiar with, having grappled with key concepts in case law in the area of defamation in particular. This can be seen from the Fevaworks case (as discussed above) ${ }^{56}$, which derived some of its analysis from UK case law and in particular Tamiz v Google Inc. ${ }^{57}$ In fact, alongside the recent UK reforms of defamation laws, this Hong Kong case is billed to provide a 'stimulus for a necessary review of the law relating to internet intermediaries in Hong Kong.${ }^{58}$ UK concepts have already got some impact on the way Hong Kong law is shaped. One may therefore advocate for letting judges use the common law to bridge the liability gap. However, legal certainty is an important factor to attract businesses such as online auction platforms and foster the further development of electronic and e-commerce in Hong Kong. This is hard to achieve it if some key legal concepts are not carefully framed. Guidelines in statutes would therefore be welcome in Hong Kong in the absence of established case law guiding any interpretation. In

\footnotetext{
56 [2013] 16 HKCFAR 366.

57 [2012] EWHC $449(\mathrm{QB})$.

${ }^{58}$ Ong (n 17) 136.
} 
fact, the Copyright (Amendment) Bill 2014 serves as a useful guide in determining ISPs' liability, although it is only catered for copyright liabilities. The authors strongly favour the use of the EU regime to assess the conditions that need to be complied with in order to be exempted from liability. It is however noted that it is by no mean a perfect standard and its operation in Hong Kong would need to be adapted and clarified in places as the below explains.

\subsection{The evolving liability of online auction site in Europe}

The EU regime is built around Article 14 ECD. One interesting aspect of the EU regime is that it has evolved with market conditions. The initial wording of Article 14 has not been changed but its interpretation has shown that the EU regime is adaptable, a characteristic which would benefit any new Hong Kong regime to be put in place. Indeed, the received wisdom was that while intermediary online auction sites and other intermediaries could do more to eradicate dubious practices on their sites, the ECD was simply not forcing them to do so. ${ }^{59}$ In that sense, the EU regime was for many years akin to the US regime where the liability of hosts seemed contained and any prospects of a successful lawsuit was illusory ${ }^{60}$ However, a general shift towards more liability occurred from $2008 .^{61}$ If the absence of liability under the ECD seemed justified for intermediaries who did not directly benefit from the illegal activities perpetrated on their site, the position of online auction platforms and market places was perceived, by

\footnotetext{
${ }^{59}$ For more on the evolution of the liability of online auction sites in the EU, see Riefa (n 36).

${ }^{60}$ See Andrès Guadamuz Gonzàlez, 'Developments in intermediary liability', in Andrej Savin and Jan Trzaskowski, Research Handbook on EU Internet Law (Edward Elgar 2014) 312-36.

${ }^{61}$ For more details on case law in the EU and in particular, France, Germany, Belgium and the UK, see Riefa Consumer Protection and Online Auction Platforms (n 3) 182.
} 
many, as different because the sites by and large receive commission even on the sale of counterfeit goods. $^{62}$

The Court of Justice of the European Union (CJEU) took position in a series of cases, the latest of which, L'Oréal SA and Others veBay International AG and Others ${ }^{63}$ opposed a well-known brand of cosmetics and the leading online auction site in the EU. It decided to significantly reduce the scope of protection granted to hosting intermediaries ${ }^{64}$ by devising a liability test that adds new requirements to the pre-existing wording of Article 14 ECD:

- Only 'neutral hosts' are granted immunity.

- The neutral host also needs to behave like a 'diligent economic operator' in its discovery and removal of litigious materials.

- It is now possible to impose some restricted monitoring obligations on online auction intermediaries under certain circumstances.

\subsection{The Neutrality test as standard for immunity threshold}

According to the CJEU, hosting services do not benefit from an automatic exemption of liability, but rather from an exemption on condition that they are 'neutral', an interpretation it had

\footnotetext{
${ }^{62}$ Riefa, above $\mathrm{n} 36$.

${ }^{63}$ C-324/09, L'Oréal SA and Others v eBay International AG and Others [2011] I-06011. For more on the facts of the case and trademark issues covered, see Christine Riefa, 'The end of Internet Service Providers liability as we know it' - Uncovering the consumer interest in CJEU Case C-234/09 (L'Oréal/eBay) (2012) euvr 1(2) 104111.

${ }^{64}$ Christine Riefa, 'The end of Internet Service Providers liability as we know it' (n 63) 104.
} 
already adopted in the a series of cases concerning the liability of Google (search engine). ${ }^{65}$ The CJEU decided to embed that neutrality was a prerequisite to benefit from the exemption of liability under Art 14 ECD regardless of the type of site the test is applied to. The court indeed uses the same standard for online auction site that it used for search engines. From a legal analysis perspective, the CJEU's approach rests uneasily with some commentators and judges. ${ }^{66}$ But it has the benefit of creating a unique set of tools to evaluate liability, regardless of the subject matter, and to look at liability of intermediaries in a more objective way. This is a standard which would be most beneficial to use in Hong where presently is governed by a number of different laws, contributing to uncertainty.

\subsubsection{Assistance as a key factor to assess neutrality}

The CJEU in L'Oréal veBay ${ }^{67}$ decided that Article 14 ECD 'must be interpreted as applying to the operator of an online auction marketplace where that operator has not played an active role allowing to have knowledge or control of the data stored'. ${ }^{68}$ This presents some challenges

\footnotetext{
${ }^{65}$ Joined cases Google France SARL, Google Inc v Louis Vuitton Malletier SA (C-236/08) v Viaticum SA, Luteciel SARL (C-237/08) and Google France SARL v Centre National de recherche en relations humaines (CNRRH) SARL, Pierre-Alexis Thonet, Bruno Raboin, Tiger SARL (C-238/08) [2010] I-02417.

${ }^{66}$ Patrick Van Eecke, 'Online service providers and liability: a plea for a balanced approach' (2011) 48

C.M.L.R. 1483. See also for a critical view, Ian Walden, 'Mine host is searching for a "neutrality” principle', Queen Mary University of London, School of Law, Legal Studies research paper No. 34/2009; Kaschke v Gray and another [2010] EWHC 690 (QB) para 46. Stadlen J commented that he found Recital 42 a somewhat 'curious recital' (at para 44), and was sympathetic to the view of the Advocate General finding that Recital 42 did not sit easily with Recital 46 (at para 45).

${ }^{67}$ L'Oréal (n 63).

${ }^{68}$ Ibid ruling 6. At para 112, the Court stated that it was 'essential' that the provider be an intermediary within the meaning intended by the legislature, i.e. a 'neutral' host (under the interpretation the CJEU gave of the intentions of the legislature it referred to). The Court added at para 113: 'this is not the case where the service provider instead of confining itself to providing that service neutrally by a merely technical and automatic processing of
} 
that ought to be settled by statute in Hong Kong concerning the notion of what is an active role (or a neutral one). The court focused on assistance as a key factor to assess neutrality, a notion not defined in the ECD. It explained that when assistance is provided, the online auction platform ' $m u s t$ be considered not to have taken a neutral position' ${ }^{69}$ But the notion of 'assistance' is not neatly packaged in the decision nor is it neatly described. It is defined, through a nonexhaustive list of examples, and by opposition to neutral activities. The CJEU noted that

the mere fact that the operator of an online marketplace stores offers for sale on its server, sets the term of its service, is remunerated for that service and provides general information to its customers cannot have the effect of denying it the exemption from liability provided by $\mathrm{Di}$ rective $2000 / 31 .^{70}$

By contrast, the CJEU found that where

the operator has provided assistance which entails, in particular, optimising the presentation of the offers for sale in question or promoting those offers, it must be considered not to have taken a neutral position between the customer seller concerned and potential buyers, but to have played an active role of such kind as to give it knowledge of, or control over, the data relating to those offers for sale. ${ }^{71}$

the data provided by its customers, plays an active role of such kind as to give it knowledge of, or control over those data'.

${ }^{69}$ Ibid para 116.

${ }^{70}$ Ibid para 115.

${ }^{71}$ Ibid para 116. 
'Assistance intended to optimise or promote certain offers for sale' therefore tips the balance towards an active role. ${ }^{72}$ Strictly speaking the court identified four ways in which eBay probably assists sellers. ${ }^{73}$ They are:

- assisting sellers in order to enhance their offer for sale,

- $\quad$ setting up online shops,

- promoting and increasing sales

- advertising products on search engines such as Google.

The intensity in the assistance provided is an important factor that ought to be assessed. The CJEU suggests that assistance, which entails optimisation of the offers, gives the online auction intermediary an active role, barring immunity. The concept of 'optimisation' however is not explained and is actually used as a synonym of 'enhancement'. ${ }^{74}$ Yet, according to the Oxford Dictionary, to 'optimise' is to make the best or most effective use of something. By contrast, to 'enhance' means to 'intensify or improve'. Both terms communicate a similar idea, but they are in fact different degrees of improvements. Optimisation is a higher form of enhancement, a distinction not made clear by the CJEU. It results that any activities below this enhancement threshold, so to speak, remain neutral. Anything above will potentially render the intermediary active. The question therefore is to define what services or activities carried out by an online auction site will provide assistance in optimising (or enhancing) the presentation of an offer of such nature that they will give the intermediary an active role of such a kind so as to give it

\footnotetext{
72 Ibid para 114.

${ }^{73}$ Ibid para 31.

${ }^{74}$ Ibid para 31.
} 
knowledge or control over the data held. This may for example be the case for gallery upgrades, ${ }^{75}$ listing designer services ${ }^{76}$ or the status of PowerSeller or other preferential status, none of which were discussed by the CJEU.

\section{3. 'Control' over the data hosted as a prerequisite for loss of neutrality}

Assistance does not necessarily lead to activity if the intermediary does not gain any control over the data. Indeed, the test established by the CJEU is a two-prong test. Assistance has to lead to control in order to lead to activity versus passivity. This was for example, the conclusion reached in the case of Maceo. ${ }^{77}$ In this case, the French court discussed feedback mechanisms; classification tools destined to categorise, enhance listings and facilitate the use of the service offered by eBay; email or text alerts on listings; payment via PayPal; the automatic promotion of listings; and the provision of management tools to sellers. ${ }^{78}$ The court applied the neutrality test but found that the technical operations consisting in presenting and organising the data as well as classification tools did not imply a selection and a control over the data put online and were inherent to the provision of hosting services. In this case, eBay was considered a neutral host. This was because those tools improved the visibility of listings, facilitated the search and sale of items and informed buyers on the content of listings and the reliability of sellers. Such features did not confer on eBay an active role giving it knowledge or control over data it hosts. However, the CJEU neglected to clarify if a combination of neutral services can amount to an

\footnotetext{
75 Gallery upgrades highlight pictures so they catch buyers' attention and show items in more detail, $<$ http://pages.ebay.co.uk/help/sell/gallery-upgrade.html> accessed 24 May 2016.

${ }^{76}$ Listing designer is a tool to improve the visual appeal and create a professional look and feel without using HTML < http://pages.ebay.co.uk/help/sell/listing-designer.html> accessed 24 May 2016.

77 TGI Paris, 3ème Ch 1ère Section, 10/11914, SARL MACEO c/ Société eBay International AG, 13 March 2012

78 For example Selling Manager <http://pages.ebay.co.uk/selling_manager $>$ and turbo lister $<$ http://pages.ebay.co.uk/turbo_lister/?ssPageName=SRCH_KNM_URLM $>$ both accessed 24 May 2016.
} 
active role being played, or if one particular activity will automatically tip the provider into 'activity'. Although the accumulation of activities is likely to make a more convincing case for an online auction intermediary being active rather than neutral, the French court did not think that the accumulation of services offered was sufficient in this instance.

\subsection{1 'Relationship' and 'payments' as more viable criteria to assess assistance and neutrality}

When listing items on intermediary websites, some basic services tend to be free, but more advanced features and services normally need to be paid for, thus providing the website with an additional revenue stream. In Google, Advocate General Poiares Maduro pointed out that the search engine was neutral when it comes to natural results, i.e. results that are the product of automatic algorithms generating links. This was because those results are ranked and presented by reference to their relevance to the keyword searched and not based on Google's interest in bringing any particular site to the user's attention. By contrast, Google is active when users are paying Google so that results are prominently displayed through Adword. ${ }^{79}$ The notion of a 'relationship' is not a criterion discussed in L'Oréal v eBay. Yet, it appears a viable alternative to the notion of optimisation. AdWords is a service that optimises the visibility of the search results. By analogy, online auction sites could be considered neutral when hosting data posted by users via their most basic listing service, but could lose such classification when users make use of features enabling their listing to 'stand out' and decide to opt for a subtitle or additional photos for example. In those cases, the online auction platform or market place has a more closely defined vested interest in the sale and better knowledge and control over the data, since it will have taken payment for some of the features used by the seller. ${ }^{80}$

\footnotetext{
${ }^{79}$ Maduro, Opinion delivered on 22 September 2009, Cases C-236/08 to C-238/08, Google, para 145.

${ }^{80}$ See also Dr Yeung Sau Shing Albert v Google Inc [2014] 5 HKC 375.
} 
In order to characterise knowledge or control it seems that payment, which the CJEU was quick to discard in both Google and L'Oréal, also is a viable factor of assessment that ought to be pondered in Hong Kong when considering a new uniform test for all online intermediaries. For example, in GEMA v RapidShare, ${ }^{81}$ Germany's Bundesgerichtshof found that the file-hosting service facilitated copyright infringements and lost its neutral role because it offered 'premium accounts' for remuneration which were only attractive and useful for sharing illegal content. Those accounts provided financial incentives based on the number of downloads. ${ }^{82}$ Payments cannot be considered in isolation, but ought to be considered alongside the 'relationship' developed by the parties and the involvement/role played by the online auction platform. Indeed, by receiving remuneration for the services in question, online auction platforms both forge a relationship with the sellers and, through payment, acquire the knowledge and some control over the data hosted. But such control could also be acquired without any payment and thus payment in itself is not an absolute test for control. However, processing the payment for the corresponding data to be hosted is very likely to provide knowledge. Similarly, in the absence of payment, it is very likely that any additional photos or premium features would no doubt not be disclosed by the online auction site thus giving it control.

The link between a 'relationship' and knowledge or control over data is even more apparent when considering the assistance provided to PowerSellers, top-rated traders, as well as to users opening an eBay shop (or equivalent services on other online auction intermediary sites). Those sellers are the best-performing sellers. Their performance is acknowledged and rewarded with privileges. According to the CJEU in L'Oréal, a shop is an activity where sellers are assisted

\footnotetext{
${ }^{81}$ GEMA v RapidShare (File-Hosting Service), BGH 15 August 2013, I-ZR 80/12.

${ }^{82}$ Anette Gärtner and Andreas Jauch, 'Gema v RapidShare: German Federal Supreme Court extends monitoring obligations for online file hosting providers' (2014) 36(3) Eurepean Intellectual Property Review 199.
} 
by eBay, ${ }^{83}$ a conclusion also reached by the French Cour de Cassation in Christian Dior, where eBay was found to have an active role based on features such as personalised selling spaces (eBay shops) and the use of trading assistants. ${ }^{84}$

\section{Framing the Knowledge and Awareness of the Diligent Economic Operator}

The second hurdle in the liability test defined by the CJEU in L'Oréal v eBay is to remove the unlawful material expeditiously on gaining knowledge or awareness of its existence. But defining the standards of knowledge or awareness sufficient to trigger liability, and how such knowledge is acquired, are not straightforward. This test has become even more cumbersome since the CJEU introduced a new reference point ('the diligent economic operator') that does not feature in the original text of Article 14 ECD. The standards of knowledge required here are different from the ones explored when testing neutrality. Indeed, to test neutrality, the notion of knowledge is coupled with 'control over the data'. If the hosting activity gives the online auction platform knowledge or control over the data, it will be deemed 'active'. Knowledge, in this second step of the liability test, is used in a different context. While to test neutrality knowledge concerns the existence of the data, at this stage the required knowledge is one of the illegality of the content in question.

\subsection{Defining knowledge and awareness}

The notions of knowledge and awareness, while used by the Electronic Commerce Directive, are not defined. It is for the national courts to interpret those notions by reference to national

\footnotetext{
${ }^{83}$ L'Oréal (n 63) para 31.

${ }^{84}$ CCass, Société eBay Inc c/ Société Parfums Christian Dior, et autres, 3 May 2012.
} 
standards. ${ }^{85}$ Some authors have questioned if the two notions are actually the same. ${ }^{86}$ But it seems more appropriate to conceptualise 'actual knowledge' and 'awareness' as different levels of a same duty of care. 'Actual knowledge' is not a mere suspicion or assumption ${ }^{87}$; it excludes construed knowledge (i.e. where the provider ought to have known of or have good reasons to suspect illegal activity). ${ }^{88}$ There is a clear difference between 'actual knowledge' and a requirement that the online auction platform be 'aware' of facts or circumstances from which the illegal activity or information is apparent. Although the Directive does not spell it out clearly, the reason for such difference is explained by the fact that 'actual knowledge' applies to criminal liability (the most demanding benchmark), whereas for claims for civil damages, 'awareness' is sufficient to trigger liability under EU law.

'Awareness' is normally a standard that applies by reference to the reasonable man. An online auction site would be deemed to be "aware of circumstances from which it would have been apparent to the service provider that the activity was unlawful" if a reasonable man, with the same knowledge, would have reached the conclusion that the activity or the information in question is illegal.

\subsection{Who is the diligent economic operator?}

When what is at stake is civil liability the threshold of knowledge is lowered. However, there still needs to be a defined cutting point at which the intermediary acquires sufficient awareness to justify liability in a claim for damages. In L'Oréal v eBay the CJEU explains that

\footnotetext{
${ }^{85}$ Van Eecke (n 66) 1475.

${ }^{86}$ Diane Rowland, Uta Kohl and Andrew Charlesworth, Information Technology Law (4th edn, Routledge 2012) 86.

87 Jääskinen, Opinion, delivered on 9 December 2010, Case C-324/09 L'Oréal para 162.

${ }^{88}$ Ibid para 163.
} 
it is sufficient in order for the provider of an information society service to be denied entitlement to the exemption from liability provided under Article 14 of Directive 2000/31, for it to have been aware of facts or circumstances on the basis of which a diligent economic operator should have identified the illegality in question and acted in accordance with article 14(1)(b) of Directive 2000/31.

The 'diligent economic operator' is therefore substituted to the reasonable man as a reference point to assess the liability of online auction sites and market places. The CJEU, however did not elaborate or define the notion and how it may differ from national frames of reference. ${ }^{89}$ More is likely to be expected from the diligent economic operator. Indeed, the Oxford Dictionary defines 'diligent' as meaning hard working or showing care and effort. Thus, the obligations of the diligent economic operator revolve around a duty to remove all material this operator can identify as illegal, not simply when the material is clearly illegal but also when a little more hard work may be required to uncover this illegality. But one other important consideration to factor in is also its knowledge of the platform operated by such diligent economic operators. The reasonable man is an objective standard, but the diligent economic operator test is applied with the knowledge and expertise the operator in question has and the amount of control the operator has and his ability to do something about the illegal material discovered.

Further, Kaschke v Gray established the principle (obiter) according to which awareness needs to also be interpreted by reference to the apparent illegality of an activity or information hosted

\footnotetext{
${ }^{89}$ In France for example it is the 'bon père de famille', the good father, the good family man that is used as a standard.
} 
by the online auction platform..$^{90}$ The display of pornographic images depicting children is undoubtedly illegal and should prompt the reasonable man as well as the diligent economic operator to remove content. This type of material is 'obviously' ${ }^{91}$ illegal. However, the sale of a fake handbag or a perfume via parallel import, is a lot more difficult to detect and identify as illegal activity or information. ${ }^{92}$ There will be situations where the seller in the text of the advert itself declares the fake nature of the product. Then the illegality ought to be apparent. But when it is not, it is not clear if the diligent economic operator should be able to tell that a handbag is fake or that a perfume was destined for another market when the reasonable man surely was not be able to. ${ }^{93}$ Those questions were not answered by the CJEU and ought to nevertheless be considered for any new legislation in Hong Kong.

\subsection{Ways to acquire knowledge or awareness}

A number of Member States in the EU have opted for a system based on presumptions where 'actual knowledge', and by default 'awareness', is often presumed if the online auction provider has received notification of a court order $^{94}$ or a notice to take down 'illegal' information

\footnotetext{
90 [2010] EWHC 690 (QB).

${ }^{91}$ Van Eecke (n 66) 1467.

${ }^{92}$ For more on the difficulties of telling content apart and the definition of actual knowledge, see Thibault Verbiest, Gerald Spindler, Giovanni Maria Riccio and Aurelie Van der Perre, 'Study on the liability of internet intermediaries' (12 November 2007) 14-5 <http://ec.europa.eu/internal_market/e-commerce/docs/study/liability/final_report_en.pdf> accessed 24 May 2016.

${ }^{93}$ By contrast, in Yinian (Shanghai) Garments Trading Co. Ltd v Zhejiang Taobao Network Co. Ltd and Du Guofa, under Chinese law, seven notifications regarding infringements were sufficient to give the platform sufficient knowledge not just of those infringing activities but also of others.

${ }^{94}$ Recital 46 states in its last paragraph: 'This Directive does not affect Member States' possibility of establishing specific requirements which must be fulfilled expeditiously prior to the removal or disabling of information.'
} 
or content. But 'awareness' could also be acquired through the intermediary's own investigations. A clear system for acquiring awareness and/or knowledge is important and ought to be considered in Hong Kong to avoid any of the inconsistencies of the EU system.

\subsubsection{Notice and take down procedures}

Member States are able to establish procedures governing the removal or disabling of access to information akin to 'notice and take down' procedures under Article 14(3) ECD. Those were often developed on a self-regulatory basis. ${ }^{95}$ In the absence of a clear framework laid out in the ECD, practice varies from Member State to Member State ${ }^{96}$ and from operator to operator. This is not particularly helpful and a new legal regime in Hong Kong ${ }^{97}$ ought to consider opting for a uniform procedure that is sufficiently detailed to avoid any uncertainty especially when it comes to the level of details the notification ought to carry. Indeed, the CJEU, in L'Oréal v eBay noted that 'such notification admittedly cannot automatically preclude the exemption from liability provided for in Article 14 of Directive 2000/31, given that notification of allegedly illegal activity or information may turn out to be insufficiently precise or inadequately substantiated (...) $\cdot{ }^{98}$ However, the notification remains a factor for national courts to consider 'when determining, in the light of the information so transmitted to the operator, whether the

\footnotetext{
${ }^{95}$ Recital 40 ECD.

${ }^{96}$ For example, in the UK specialised procedures exist for notices in cases of copyright infringements under Section 97A of CDPA 1988 or under Section 1 of the Defamation Act 1996. Alongside, Regulation 22 of the Electronic Commerce (EC Directive) Regulations 2002 is the basis for a procedure under which actual knowledge is acquired in other contexts. In France, Article 6-I-5 of the LCEN prescribes the form a notice needs to take to create a presumption that the intermediary has acquired actual knowledge. For more details on the different notice and take-down procedures adopted by Member States, see Verbiest et al. (n 92) 41-6.

${ }^{97}$ Reference can be made to Section 88C of the Copyright (Amendment) Bill 2014 which spells out the form and procedure of serving notice regarding alleged infringement.

${ }^{98}$ L'Oréal (n 63) para 122.
} 
latter was actually aware of facts or circumstances on the basis of which a diligent economic operator should have identified the illegality.${ }^{99}$

Only a notification that is sufficiently precise and substantiated is capable of triggering 'awareness'. ${ }^{100}$ Yet, appreciating what is sufficiently precise and substantiated is not straightforward because even national standards are not clearly defined. In the UK for example, Regulation 22 of the Electronic Commerce (EC Directive) Regulations 2002 only defines 'notices for the purpose of actual knowledge'. It does not define awareness. ${ }^{101}$

In Bunt v Tilley, ${ }^{102}$ mention of the presence of defamatory materials in an email sent to BT, the host of a Usenet newsgroup on which the litigious materials were placed, was not deemed sufficient to constitute notice under Regulation 22(1)(b). Eady J explained that the email did not fulfill the legal requirements of Regulation 22(1)(b)(ii) and (iii) because none of the required information was included. Particularly on point (iii), Eady J observed (obiter) that 'in

\footnotetext{
${ }^{99}$ Ibid. para 122.

${ }^{100}$ Note that the CJEU only commented on the notion of 'awareness' in L'Oréal (n 63) since the main proceedings were geared towards the award of damages and thus did not discuss 'actual knowledge'.

101 This Regulation states:

"In determining whether a service provider has actual knowledge for the purposes of regulations $18(\mathrm{~b})(\mathrm{v})$ and 19(a)(i), a court shall take into account all matters which appear to it in the particular circumstances to be relevant and, among other things, shall have regard to -

(a) Whether a service provider has received a notice through a means of contact made available in accordance with regulation $6(1)(\mathrm{c})$, and

(b) The extent to which any notice includes -

(i) The full name and address of the sender of the notice;

(ii) Details of the location of the information in question; and

(iii) Details of the unlawful nature of the activity or information in question".

102 [2006] EWHC 407 (QB).
} 
order to be able to characterise something as 'unlawful' a person would need to know something of the strength or weaknesses of available defences'. ${ }^{103}$

In Twentieth Century Fox Film Corp and several other film corporations v British Telecommunications ${ }^{104}$ the High Court of England and Wales took position on the notion of 'actual knowledge' and the form of a notice. One of the issues at stake was that Section 97A(1) of the CDPA $1988^{105}$ enables copyright holders to seek injunctions against service providers, 'where that service provider has actual knowledge of another person using their service to infringe copyright'. Although this case was not directly concerned with the application of the Electronic Commerce Directive, and did not concern a host (but an intermediary acting as mere conduit), it was the first English case to discuss the CJEU's decision in L'Oréal v eBay. In addition, it was Arnold J's view that the requirement for actual knowledge in this section was transplanted from Articles 13 and 14 of the E-Commerce Directive and the corresponding provisions of the 2002 Regulations (with only minor differences) ${ }^{106}$ meaning that findings as to the meaning of 'actual knowledge' and the form of the notice will be relevant to the way they will be interpreted under the Electronic Commerce Directive.

Arnold J concluded that 'actual knowledge' should not be interpreted too restrictively and that Section 97A(2) does not make provision of such details mandatory, or even any details: it

\footnotetext{
103 Ibid. para 72.

${ }^{104}$ Twentieth Century Fox Film Corporation, Universal City Studios Productions LLLP, Warner Bros. Entertainment Inc., Paramount Pictures Corporation, Disney Enterprise Inc., Columbia Pictures Industry v British Telecommunications Plc [2011] EWHC 1981 (Ch).

105 This section implements into UK law Article 8 Directive 2001/29/EC of 22 May 2001 on the harmonisation of certain aspects of copyright and related rights in the information society (the Information Society Directive).

106 Arnold J at para 137.
} 
merely requires the court to 'have regard to the extent to which any notice includes such details'. ${ }^{107}$ This suggests that not all details are necessary for the provider to have acquired actual knowledge. The judge did not require actual knowledge of a 'specific infringement or a specific copyright work by a specific individual'. Hence, the more detailed the notice, the more likely it will be that a court concludes that the provider had knowledge and, by default, sufficient awareness. In the end, what it turns on is that the notice be 'sufficiently detailed and gives a reasonable opportunity to investigate the position', ${ }^{108}$ an interpretation consistent with the CJEU's requirements in L'Oreal v eBay.

4.3.2 Intermediaries' own investigations in the acquisition of knowledge and awareness

According to the CJEU, this may be one way for the provider to become aware of facts or circumstances on the basis of which a diligent economic operator should have identified the illegality. ${ }^{109}$ In the aftershock of the L'Oréal decision it does not seem possible for online auction platforms to simply await notifications before acting. However, it remains unclear if a diligent economic operator has to proceed with investigations on a regular basis or in any particular fashion or if it can wait to be prompted. Yet, the fact that the standard has moved from the 'reasonable man' to the 'diligent economic operator' requires more regular checks and any notification, even if vague, should prompt further investigation to fulfill that standard. The law would benefit from spelling out the way in which those checks ought to take place and how far they have to go to be satisfactory.

\footnotetext{
${ }^{107}$ Ibid para 137.

108 Ibid para 149.

${ }^{109}$ For example, in the case of $e B a y c / D W C$ it is as a result of eBay's own investigation, following the site becoming aware of a press article criticising one eBay trader, that eBay closed without warning four accounts held by DWC.
} 


\section{Obligations of the Online Auction Platform on Acquiring the Required 'Knowledge' or 'Awareness'}

Where it can be established that a neutral online auction platform has acquired actual knowledge or awareness, the intermediary is under an obligation to remove access to the litigious material expeditiously under Article 14(1)(b) ECD. If the online auction provider does not comply it can be subject to injunctions to force compliance. Under Article 14(3) ECD it is possible for courts or administrative authorities to force providers to terminate or prevent an infringement or establish procedures governing the removal or disabling of access to information but injunctions can also be adopted without the need to show that a provider had actual knowledge or awareness of particular infringements.

\section{1 'Expeditious' Removal of the Illegal Material}

Expeditious take down is required upon discovery. However, it is unclear how quickly the take down must take place to benefit from the immunity granted by the Directive and more precise guidelines are necessary. ${ }^{110}$ In particular, in cases where the provider is on notice, pressure may be felt to remove material as soon as possible, so as not to engage liability. Unscrupulous competitors may however use notice and take down procedures as a means to impede sales on online auction websites, and caution may therefore be required. ${ }^{111}$ In addition, information is

110 Lilian Edwards, 'The fall and rise of intermediary liability online' in Lilian Edwards and Charlotte Wealde (eds), Law and the Internet (3rd edn, Hart 2009) 66.

${ }^{111}$ In another context, see Jennifer M. Urban and Laura Quilter, 'Efficient process or "chilling effects"? Take down notices under Section 512 of the Digital Millennium Copyright Act' (2006) 22 Santa Clara Computer \& High Tech. L.J. 621-93. The extent of use of notices against competitors in this study of take down notices under Section 512 DMCA noted that $55 \%$ of notices received by Google were competition related (at 651 ). 
often difficult to confirm as infringing or more generally as being 'illegal'. The provider may therefore need to take some time after receipt of the notice to decide if take down is required. Some research conducted with a sample of UK ISPs and hosts showed that 'take-down periods varied hugely from 24 hours to about a week, depending on the type of content and the size of the organisation'. ${ }^{112}$ However, in the context of auctions or market place sales, the speed of removal should be relatively short because auctions or sales have a limited life span of normally a few days. Therefore, if removal does not happen before the expiry of the sale, the process is ineffective. Organisations will continue to vary in size and financial might, and not all online auction providers will be able to locate information and decide on its 'legality' at the same speed. This may be because of a shortage of qualified staff or because of a large volume of sales hosted on the site. The speed of removal would also depend on how knowledge or awareness is acquired. If it is acquired via a precise and substantiated notice, one would expect take down times to be shortened, because the details concerning where on the server the information is placed, will be provided to the intermediary. Therefore the current solution prevailing in the Copyright (amendment) Bill 2014 in Hong Kong, which leans towards immediate removal, may be a workable solution for online auction sites but would need some amendments to adapt it to the nature of the auction business. At least an interim suspension while the provider investigates ought to be considered. If it was used, it could suspend the auction and restart the clock when the auction is reinstated. Less than precise notice may require a longer lead time; so will information the intermediary stumbles across, if verifications concerning the legality of the information are necessary. Here possibly the quality of the software used by the intermediary to track activity and the technology used to detect illegal activity will also have to be taken into account.

${ }^{112}$ Edwards (n 110) 66. 


\subsection{The Prevention of Future Infringements}

A really useful tool to prevent illegal activity on intermediary websites is to rely on the platform itself to monitor activities so that they do not reoccur. Prevention is a useful policy, but in Europe, it clashes with Article 15 ECD that prevents general monitoring. The same goes with the proposal in the Hong Kong Copyright (Amendment) Bill 2014 which does not impose an obligation on intermediaries to monitor. ${ }^{113}$ Courts have therefore had to decide the limits of the obligations that can be imposed on intermediaries to control and prevent future infringements. The German Supreme Court in Rolex $S A$ v. eBay $G m b H^{114}$ overturned previous decisions which considered that eBay could not be held liable for any sale of fake Rolex watches identified as such on its site, because the intermediary was not in fact aware of the specific listings containing fake items. Rolex was asking eBay to monitor and filter new listings concerning 'noble replicas' or 'deceptively similar to the original' Rolex watches and stop any such listings from appearing on the eBay.de website. The Court rejected eBay's liability on the basis that one could not impose an obligation to monitor content on the intermediary in application of Sections 8(2), 11(1) (1) and (2) TDG (the German Teleservices Act). However, the Federal Supreme Court considered that whilst 'eBay could not be expected to examine every offer for potential unlawful content, it was nonetheless effectively participating in the sale of pirated goods via the commission it was due'. The Court decided that eBay ought to prevent, not only any specific listing, whenever its attention is drawn to it, but also use a filtering software to prevent any further infringement of the same type. There were, however, some limitations imposed by the court, and the decision was by no means the recognition of the full liability of online auction sites at the time it was taken. EBay could not be held liable for listings that

\footnotetext{
${ }^{113}$ See s 88B (5) of the Copyright (Amendment) Bill 2014.

${ }^{114}$ Rolex SA v. eBay GmbH, Bundesgerichtshof I ZR 304/01 [2005] ETMR 25, [2006] ECC 9 (Rolex I).
} 
cannot be spotted by the use of the filtering software. The Court said very little about what kind of monitoring software would be satisfactory.

The issue resurfaced in the referral to the CJEU framed within Article 11 of Directive 2004/48 because in many Member States the injunctions granted in Germany were not available (at least it was uncertain in the UK). The CJEU decided that it should be possible for national courts to order an online marketplace to 'take measures which contribute, not only to bringing to an end infringements of those rights by users of that marketplace, but also to preventing further infringements of that kind', ${ }^{115}$ potentially placing a heavy burden on online auction platforms to police their sites. However, Article 15 ECD prohibits a general obligation to monitor site activities. Any general monitoring obligations would also be contrary to Article 3 Directive 2004/48 itself, since under this Directive all measures must be fair, proportionate and not excessively costly, and must not create barriers to legitimate trade. If monitoring becomes too onerous, it is likely to be considered a barrier to trade for the website owner. It follows that the measures required of the online auction platform cannot consist in an 'active monitoring of all the data of each of its customers in order to prevent any future infringement'. ${ }^{116}$ This is far too wide.

In $S A B A M,{ }^{117}$ a case concerning a collective management company representing authors, the CJEU looked into the limits of Article 15 ECD. It found that the injunction, which imposed on an ISP an obligation to install a filtering system to prevent file-sharing was in breach of Article

\footnotetext{
${ }^{115}$ L'Oréal (n 63) para 127.

116 Ibid para 139.

${ }^{117}$ C70/10, Scarlet Extended SA v Société belge des auteurs, compositeurs et éditeurs SCRL (SABAM) [2012] ECDR 4. The findings were later followed in C-360/10, Belgishe Vereniging van Auteurs, Componisten en Uitgevers CVBA (SABAM) v Netlog NV [2012] CMLR 18. Netlog is an online social networking platform.
} 
15 ECD. This was because the injunction had no limitation in time and was directed at all future infringements of not only existing works, but also future works. This injunction obliged the ISP to actively monitor all the data relating to each of its customers in order to prevent future infringements of intellectual property rights, and amounted to general monitoring. As a result, trademark owners and others seeking injunctions cannot hope for a blanket injunction banning the sale of products on online auction sites. However, they can seek that the website is asked to monitor similar sales made by the same seller or for a seller's account to be closed in order to prevent the same seller further infringing rights in respect of the same trademark. ${ }^{118}$ Indeed, specific monitoring is something that the Bundesgerichtshof also sees as possible as long as it does not put the business itself at risk. ${ }^{119}$ Should the intermediary facilitate infringing activities, the extent of the monitoring obligations to be imposed can be widened. ${ }^{120}$ In Coty, the German court imposed the filtering of offers by keywords in both the offer titles and their descriptions. It concluded that eBay needed to prevent infringing offers from being posted in future, in so far as this was reasonable. It added that automatic filtering did not exclude that some degree of manual inspection can reasonably be expected. ${ }^{121}$

\footnotetext{
${ }^{118}$ However, this may have to be balanced with freedom of expression and other rights such as data protection. For more on those questions, see Van Eecke (n42) 1455-502. This measure alone is very likely to change the way online auction platforms proceed to monitor/uncover infringements on their websites because it gives a clear licence to intellectual property owners to apply for injunctions against online auction intermediaries, many a time easier to locate than the infringers themselves. But to prevent future infringements, the CJEU allowed that online auction sites be ordered to take measures to make it easier to identify intellectual property infringers, facilitating the pursuit of claims against primary infringers, suggesting that IP owners will have to continue to pursue direct infringers.

119 Atari v RapidShare (Alone in the Dark), BGH 12 July 2012, I-ZR 18/11.

${ }^{120}$ GEMA (n65).

${ }^{121}$ Coty Germany GmbH v eBay International AG [2012] ETMR 19.
} 


\section{Conclusion}

Online auction intermediaries and other market places are well established in Hong Kong. When acting as hosts, their legal obligations are uncertain because Hong Kong Law is not yet defined in this area. The liability gap in Hong Kong will most likely require legislative intervention. Out of the possible models for intervention, the EU approach of offering a uniform test for different liabilities and different intermediaries offers a viable starting point. It is because intermediaries will be subject to the same test and with the regime having grown across the years and refined by case law, more certainty can be achieved. While developed at a time where imposing liability was seen as an impediment to electronic commerce, the latest wave of cases indicate a push towards a more responsible industry where only neutral hosts can escape liability. The standard for liability has thus been raised. However, the EU model, also needs to be refined and adapted in Hong Kong. Refinement will center around adapting the legal regime to the geographical and cultural environment, but also improving on the way the CJEU went about defining a new legal regime, not apparent from the wording of Article 14 ECD. The way this liability or lack of immunity under Article 14 ECD is to be assessed indeed remains unclear and will no doubt lead to further conflicts in interpretation as national courts grapple with the concepts of 'neutrality', 'diligent economic operator', 'expeditious removal' and the monitoring and prevention of future infringements. The route chosen by the CJEU to assess liability is a test that requires the intermediary to behave in a neutral way if it wishes to benefit from the immunity that Directive 2000/31/EC provides. Yet, neutrality is not defined in the Directive or in national law, and the CJEU gave little by way of explanation on how to interpret it. The neutrality test developed by the CJEU primarily rests on assessing the 'assistance' the online auction host provides to its users. However the legislator in Hong Kong ought to frame the test as a two-pronged test, where assistance is assessed by reference to the level 
of relationship developed between the platform and its user. It is primarily the degree of assistance that needs to be assessed, on a case-by-case basis, to determine the role played by the online auction platform. In addition, such relationship needs to be assessed by reference to the degree of knowledge or control it gives the online auction platform over the data hosted. Therefore, a loose relationship without knowledge or control over the data would return an assessment of neutrality, and thus immunity for the platform. By contrast, the closer the ties, the more developed the knowledge of or control over the data hosted. Not defining this notion careful would mean that it remains a moving target and impact on legal certainty.

A second hurdle, once neutrality has been established, is to show that the intermediary has knowledge or awareness of facts or circumstances pointing to the illegality of content. This is not always an easy task because the way such knowledge or awareness is acquired is again not defined in the ECD and here again more details may need to be defined to offer a more workable system in Hong Kong. In particular, the difference of thresholds between infringements leading to criminal sanctions (knowledge standard) and those leading to civil remedies only (awareness standard) many need to be more carefully thought out as well as the level of details required for notice and take down and how knowledge following a notice may be constituted. More importantly, defining who a 'diligent economic operator' is appears essential. The notion is not defined under EU law with potentially damaging consequences to legal certainty. We believe that expectations are higher on the diligent economic operator than they have otherwise been by reference to other standards such as the 'reasonable man', thus pushing online auction sites to be more proactive in their dealing with data they host on their servers but it is currently not clear if it would be the case. The adoption of such an interpretation in Hong Kong would have the benefit of ensuring stronger protection for users of online auction platforms and market places. This however needs to be balanced in light of the actual 'health' of the market, in 
order to ensure that too strong protection will not stifle the development of electronic commerce in this area.

The third step, once knowledge or awareness is established, is to proceed with expeditious removal of the material in question. This is here again an area where some confusion reigns in Europe, as the length of time required to proceed with this varies. More importantly, once data has been removed the delicate question of monitoring data to avoid repeat infringements is still debated by the courts. The limits of Article 15 ECD seem to guard against general and allencompassing monitoring obligations. However, specific monitoring, which can be more or less demanding, depending on the sites' involvement, is perfectly feasible. Its limits ought to be considered by the Hong Kong legislator in order to strike a feasible balance between IP owners, consumers and online auction platforms and market places' interests. 